\title{
Placing the View from Nowhere: Historical and Sociological Problems in the Location of Science
}

\section{Citation}

Shapin, Steven. 1998. Placing the view from nowhere: Historical and sociological problems in the location of science. Transactions of the Institute of British Geographers NS 23(1): 5-12.

\section{Published Version}

doi:10.1111/j.0020-2754.1998.00005.x

\section{Permanent link}

http://nrs.harvard.edu/urn-3:HUL.InstRepos:3353810

\section{Terms of Use}

This article was downloaded from Harvard University's DASH repository, and is made available under the terms and conditions applicable to Other Posted Material, as set forth at http:// nrs.harvard.edu/urn-3:HUL.InstRepos:dash.current.terms-of-use\#LAA

\section{Share Your Story}

The Harvard community has made this article openly available.

Please share how this access benefits you. Submit a story.

Accessibility 


\title{
Placing the view from nowhere: historical and sociological problems in the location of science
}

\author{
Steven Shapin
}

\begin{abstract}
Over the past two decades broadly geographical sensibilities have become prominent in the academic study of science. An account is given of tensions in science studies between transcendentalist conceptions of truth and emerging localist perspectives on the making, meaning and evaluation of scientific knowledge. The efficient spread of scientific knowledge is not a phenomenon that argues against the applicability of geographical sensibilities towards science but actually calls for an even more vigorous project in the geography of knowledge.
\end{abstract}

key words science localism universalism standardization meaning

Department of Sociology, University of California, San Diego, La Jolla, California 92093-0533, USA

revised manuscript received 6 September 1996

That the academic study of science owes anything at all to the sensibilities and resources of geographers is a remarkable circumstance. ${ }^{1}$ Of all forms of cultural practice the geographical - and, more generally, the spatial or local - perspective on the natural sciences seems most difficult to sustain. After all, both common and philosophical usage testify to the very nature of authentically scientific ideas as disembodied and their scope as universal. That, indeed, is one way in which we recognize ideas as scientific, compared to folk knowledge, political thought, religion, ideology and science's poor relations in the less favoured suburbs of the academic grove: sociology, history, even geography itself.

Emile Durkheim, for example, contrasted the local imprint borne by religious and lay belief with the universality of science: 'the truths of [modern] science', he wrote, 'are independent of any local context $^{\prime 2}$. And, while post-Popper philosophers were willing to acknowledge that the production of scientific ideas was thoroughly bound up with the psychologically idiosyncratic and the culturally variable, they nevertheless insisted that the context of justification - the transformation of idea into knowledge - was a matter of context-free reason and logic. That is the obstacle faced by the geographical sensibility towards science and, arguably, towards any body of knowledge which counts as truth for the relevant culture - whether mathematics and science today or Christian religion in the European past. Truth is - and, arguably, always has been - the 'view from nowhere' and the claim that knowledge is geographically located is widely taken as a way of saying that the knowledge in question is not authentically true at all. ${ }^{3}$

It is against this background that the rise of a geographical perspective on science in recent years is so remarkable. ${ }^{4}$ Starting in the early 1970 s, we have had studies of local scientific cultures, national or regional, notably including a body of detailed work on science in the Scottish Enlightenment. ${ }^{5}$ This was followed later by a revival of nineteenth- and early-twentieth-century interest in the question of nationally varying styles of science (for instance, Scottish versus English styles of mathematics and physics; the German versus the American styles of genetics). ${ }^{6}$

And then, from the mid-1980s, the geographical sensibility towards science became philosophically deeper. It began to press beyond matters of social organization and stylistic presentation, seeking to 
show that locality and spatial situation needed to be attended to in order to understand how scientific knowledge was made, how it secured credibility, how it travelled. A pluralist sensibility towards the nature of science flowed from the work of Thomas Kuhn, as developed by sociologists of science whose work Kuhn subsequently disowned. ${ }^{7}$ Science was not one thing conceptually and methodologically unified, as the seventeenth-century moderns and their followers proclaimed; it was a variety of practices whose conceptual identities were the outcomes of local patterns of training and socialization. ${ }^{8}$ One could no more hope to become a competent member of the relevant scientific community by reading its texts and methodological pronouncements than one could learn to be an English gentleman by reading a book of manners. And that was one reason why sociologists of science turned from the questionnaire and the armchair to participant observation in the laboratory. If understanding was the aim, then there was no alternative to being there, being where knowledge was made. $^{9}$

Kuhnian pluralism about scientific knowledge, and about how science was made, maintained and transmitted, was therefore an important way of opening up the possibility of geographical sensibilities. The extent to which these sensibilities have flourished in science studies is amply represented in historical and sociological writing from the 1980s. An issue of the journal Science in Context in 1991 was devoted to 'The place of knowledge'; the proceedings of a 1993 conference on 'Territorial themes in the history of science' will soon be published; there is already one collection of essays on the laboratory setting and another is in the works. ${ }^{10}$ Some of the contributors to these volumes find inspiration in the work of Scandinavian and British geographers, sociological theorists - notably Anthony Giddens - who have taken on board aspects of this geographical work, and architectural theorists of the built environment and its consequences for social interaction. ${ }^{11}$ Others have been taken with Foucault's encouragement to understand knowledge/power conjunctions as inscribed in space:

Once knowledge can be analysed in terms of region, domain, implantation, displacement, transposition, one is able to capture the processes by which knowledge functions as a form of power and disseminates the effects of power. ${ }^{12}$
Much of this work in science studies has been beautifully summarized by David Livingstone in a recent issue of Society and Space. ${ }^{13}$ Students of science owe much to geographers and it is flattering to learn that Livingstone thinks that historians of geography might possibly learn something from us. If so, it is mainly through showing some of the possibilities inherent in geographical work.

\section{Geography and the travels of knowledge}

I want briefly to describe a few of the themes represented in recent science studies work, to note how such work deploys geographical perspectives and how it confronts problems of its own making, problems which may seem to show the limits of spatial and localist sensibilities but which, I think, identify a plausible way forward. Out of a possibly much greater range of topics, I want to select just two, which I will call travel and meaning. The first, I will have to deal with schematically; the second, I will illustrate with a story.

Suppose one simply took for granted - as many philosophers and even some sociologists of science do not - a whole body of recent empirical and theoretical work showing the local, situated and embedded nature of science. That is to say, suppose one regarded it as established beyond doubt that science is indelibly marked by the local and the spatial circumstances of its making; that scientific knowledge is embodied, residing in people and in such material objects as books and instruments, and nowhere else; and, finally, that scientific knowledge is made by and through mundane and locally varying - modes of social and cultural interaction. If one granted all this, one would be treating the 'localist' or 'geographical' turn in science studies as a great accomplishment - telling us a series of important things about science which previous understandings have systematically ignored or denied.

I agree with this judgement and I do think that such work - indebted as it is to formal and informal appropriations of geographical resources - is a considerable achievement. ${ }^{14}$ And yet I also want to say that it is still incomplete and that it is in danger of missing something very important about science. The problem here is not that the geographical sensibility has been taken too far but that it has not been taken far enough. We need to understand not only how knowledge is made in 
specific places but also how transactions occur between places.

The point to which I want to draw attention concerns the issue of travel. If science is indeed a local product, how does it - or rather some versions of it - travel with what seems to be unique efficiency? How does a proposition or a procedure produced in one place come to spread across the world? One appeal of the grand modernist narratives of reason, reality and method was the table-thumping response they offered to potential questions about the travel of science. Such knowledge spreads so robustly across the world because it is true and/or because it travels along the channels carved out by unambiguous and automatically transferable methodical practices. Knowledge which is not true, or which is not so methodically grounded, does not spread. What more do you need to know?

You can, I think, plausibly reject these modernist answers to questions about travel but you cannot plausibly reject the phenomena to which they offered an explanatory response. Science is locally produced but it does travel with very great efficiency. How does it do that? If you are sceptical of the modernist responses, what interesting accounts can you give of scientific travel? And how do spatial sensibilities figure in such accounts?

The work of Bruno Latour and his followers has opened up one particularly significant line of thinking about scientific travel. ${ }^{15}$ Knowledge and technique travel insofar as they are institutionalized and standardized. The graph, the map and the book represent one set of vehicles for the efficient translation of relatively unmodified knowledge from place to place; the thermometer represents another. When knowledge of the wide world can be reduced to the scale of a table-top and when mechanically produced and virtually identical copies can be placed on table-tops everywhere, then all can (potentially and in principle) know the same world in the same ways. ${ }^{16}$ And when the thermometer becomes simply necessary for work of a range of practical communities, then the physical knowledge embodied in it becomes durable and, ultimately, incontestable. If you want to understand the robustness and the speed of scientific knowledge, you want to understand how it - and the things in which it is embodied - are distributed and held stable. That is one justification for the militaristic and imperialistic language that is so characteristic of Latour's work: he wants to draw attention to the ways in which patterns of military domination, colonialism and worldwide trade have established channels which integrate the world and which standardize its knowledge and its practices. The suggestion is that the wide distribution of scientific knowledge flows from the success of certain cultures in creating and spreading standardized contexts for making and applying that knowledge. Trace how the thermometer and its uses travelled across the world. Track how the European-style schoolroom travelled across the world. Domination, drilling and disciplining are said to be the keys to understanding how technoscientific knowledge spreads from the local to the global.

However, the 'dog' that - so to speak - 'doesn't bark' in Latour's picture of scientific travel is a conception of normative order. The Latourian account appears all natural fact and no moral fact. And for that reason, I suspect that it is at best an incomplete response to questions about the travel of scientific knowledge. Domination, drilling and disciplining are, I think, powerful means for effecting the spread of knowledge but they are quite costly means. Nor does attention to such processes pick up some much more routine and pervasive means for transferring knowledge from person to person and from place to place.

Recent science studies work on trust - including some of my own - also proceeds from a point of view on science systematically rejected by the modernist tradition going back to the seventeenth century. ${ }^{17}$ Where such moderns as Bacon, Descartes and Locke proclaimed that reliance upon human testimony was an obstacle to achieving proper knowledge of the natural world, more recent tendencies have followed Michael Polanyi in appreciating both the fact and the necessity of such reliance in securing and making sense of empirical knowledge. ${ }^{18}$ That seventeenth-century English natural philosophers knew that there were such things as icebergs and polar bears was on no other basis than what they were told by those who had seen these things, for few, if any, of them had seen them for themselves. The same goes for the phenomena produced by Boyle's air-pump in the 1660s, for only a small fraction of those who knew such facts knew them at first-hand. And the same too for the knowledge a typical modern zoologist has of the vast number of animals which constitute that discipline's factual knowledge. It is proper usage to say that Robert Boyle knew there were 
icebergs and it is proper usage to say that the typical modern zoologist knows the strange reproductive behaviour of the marine worm Urechis caupo, even though both fail to satisfy modernist criteria of direct witness. They know these things as securely as they know anything else in their domains and they know them - as it were - by courtesy.

Accordingly, a trust relationship is central to the very idea of empirical scientific knowledge. That relationship is inscribed in space: those who have not seen these things know them by trusting those who have, or by trusting those who have trusted those who have. The capacity of scientists to know what they do about the world is conditional upon finding means to bring distant things near. They can know the contents of the wide world - in space and in time - if, and only if, they have practical solvents to scepticism. Whom to trust? Answers to such a question will vary from place to place and from culture to culture but, if there is indeed to be such a thing as a body of knowledge about the wide world, there must be some answer.

The work I have been doing recently on seventeenth-century English science has pointed to the gentleman and gentlemanly identity as one very powerful answer to the question 'whom to trust?'. Many (and, in some contexts, most) scientists in the early modern period were gentlemen and their codes of scientific conduct were adapted from those circulating in gentlemanly society. Appreciations of gentle integrity, honour and free action were available to warrant belief in what these people said about the world, including the natural world to which they had access and to which others did not. Gentlemanly identity in such cultures provided adequate grounds of trust.

Late twentieth-century scientists are not gentlemen: most are not gentle and many are not men. Our late modern solutions to questions about the grounds of trust appear to be different: they seem to point towards expertise and the institutions that produce and vouch for expertise. But modern science is no less trust-dependent than science in the past or than other forms of modern culture. And arguably it is more so. The condition of scientists knowing their discipline's knowledge, and of the laity knowing what scientists know, is a massively important solution - or series of solutions - to problems of trust. That solution - and it has yet adequately to be characterized - is at the same time a solution to questions about scientific travel that have been raised by the geographical sensibility. ${ }^{19}$

\section{Geography and the meanings of knowledge}

Finally, I would like to tell a little story. It is a story about a short walk I took several years ago in London, a story about small-scale geography and a story about meaning and some of the sensibilities that historians of ideas might employ - but almost never do - in their inquiries about the meanings of texts.

When Robert Boyle lived in London from the late 1660s, he produced a number of moral as well as natural philosophical tracts. Some of these tracts identified immoral tendencies in his society and offered philosophical remedies for those tendencies. He did not, in fact, clearly specify just which circles he had in mind but recent historical studies have filled in the gaps. Boyle, it is said, was specially concerned by the radical sectarian groups that flourished during the interregnum and civil wars: Diggers, Ranters, Levellers and the like. ${ }^{20}$ Although these groups were quite effectively crushed by the Restoration in 1660, they remained paramount in Boyle's consciousness - and, indeed, in that of other Restoration moralists. They remained, so it is claimed, a potent symbol of threats to proper Christian religion and proper moral order.

That is a plausible story about the meaning of Boyle's texts and nothing I found out during my little walk counts against its plausibility. However, that walk presented me with another, quite different, plausible story about the meaning of those texts. While the first story depends upon Boyle's reaction to tendencies and behaviour with which he did not have direct familiarity (so far as we know he never met a Ranter in his life), the second story proceeds from his own day-to-day lived experience. It is about the neighbours.

I knew that Boyle's house no longer existed but I knew that it was in Pall Mall, on the south side, almost opposite St James's Square. (Strictly speaking, this was the house of his sister Katherine, Lady Ranelagh, but Boyle lived there from 1668 to his death in 1691.) I set out to find it, expecting to see a blue and white plaque commemorating his residence there for almost a quarter of a century. The site is now occupied by the western wing of the RAC - this is now, of course gentlemen's 
Placing the view from nowhere

club-land - but there was no plaque. Walking a little further to the west, there was a plaque: it commemorated not Boyle but Nell Gwyn, one of Charles II's many mistresses. A little further on lived two other royal mistresses, the Duchess of Cleveland and the Countess of Portland, and, at the western end of Pall Mall, St James's Palace itself, where the King lived. ${ }^{21}$ These were Boyle's neighbours, whose comings and goings helped form the texture of his daily experience during the years he was composing, revising and publishing some of his moral tracts.

What went on in Nell Gwyn's house - and to a lesser extent in St James's Park and the King's private garden round the back of Boyle's house $\mathrm{e}^{22}-$ is well-known. This was one of the most louche and licentious sites of Restoration debauchery and at the very highest social levels. Nell's parties - orgies actually - included not only the King and selected courtiers but also such Restoration wits and libertines as the notorious Earl of Rochester. There is also solid evidence that occasional guests included Samuel Pepys, Christopher Wren and other distinguished Fellows of the Royal Society, an organization which Boyle helped to found and of which he was a leading intellectual inspiration. ${ }^{23}$

That is, the dens of iniquity of which Boyle had the most direct and vivid experience were not those at the bottom of the social scale but those which festered at the very top, practically next door. The neighbours' goings-on may always and everywhere be a problem but these were very special neighbours. And about these neighbours you did not complain. Or, if you did, only so circumspectly or obliquely that - as the CIA used to put it - 'maximum achievable deniability' could be sustained. Boyle did not complain about the neighbours' behaviour but there are good reasons why he might not have done so while offering general indictments of immoral tendencies in his society. That kind of obliqueness was, after all, a pervasive feature of Restoration social and political commentary.

I do not necessarily offer this as a true story about the meaning of some of Boyle's moral texts but only as a plausible one. More to the point, I submit the story as a token of a possibly general approach to meaning in the history of ideas. The condition of even offering the story is an inquiry into - in this case, a walk in - the local setting of knowledge-making. And the possibility that it is a true story about meaning arises from a theory about human affections best articulated by Edmund Burke in 1790:

To be attached to the subdivision, to love the little platoon we belong to in society, is the first principle (the germ as it were) of public affections. It is a first link in the series by which we proceed towards a love to our country and to mankind. ${ }^{24}$

And the same applies where the issue is not affection but disaffection.

Burke's sensibility would suggest that we are importantly attracted to, or repelled by, ideas as they are embodied in familiar others - kin, teachers, colleagues, neighbours. That sensibility is, in my opinion, basically correct. It offers a constructive framework for empirical inquiries into the local production of meaning. Such inquiries, I think, can never be too local, and in just that sense the localist turn in science studies has a long way still to go.

\section{Notes}

1 This paper was developed from a talk to the Joint Annual Meeting of the Royal Geographical Society and the Institute of British Geographers, Strathclyde University, 4 January 1996. I thank Roger Lee for inviting me to publish these remarks and for valuable comments on the original text. The paper was completed while I was a Fellow at the Center for Advanced Study in Behavioral Sciences and I am grateful for the financial support provided by the Andrew Mellon Foundation.

2 Durkheim E ed. 1972 Selected writings (trans. Giddens A) Cambridge University Press, Cambridge 88 (quoting review originally published in 1899).

3 The phrase comes from Nagel T 1986 The view from nowhere Oxford University Press, Oxford. For the analogy between contemporary appreciations of science and nineteenth-century views of religion, see Bloor D 1988 Rationalism, supernaturalism, and the sociology of knowledge in Hronsky I Fehér M and Dajka B eds Scientific knowledge socialized Akadémiai Kiadó, Budapest 59-74; Bloor D 1991 Knowledge and social imagery 2nd edn University of Chicago Press, Chicago especially 50-3. In talking of 'truth' as pervasively 'the view from nowhere', I mean here to pick out traditional philosophical and theological conceptions of Truth as necessarily transcendent. It is by no means clear that robustly pragmatic everyday conceptions of 'what is the case' trade in notions of transcendence, nor that such mundane conceptions of truth are not central 
to some of our society's most consequential institutions and their practical judgments; consider the workings of the law, the military and medicine.

4 Among students of science there has been a loose equation between what count as geographical resources and a stress on locale and the particularities of place in knowledge-making - a circumstance which clearly arises from a desire to reject transcendentalist conceptions of scientific knowledge. The potentially useful resources of geography are not, of course, confined to those which speak of locale, though in what follows I shall largely reflect current sensibilities.

5 See, among many examples, Christie J R R 1974 The origins and development of the Scottish scientific community, 1680-1760 History of Science 12 122-41; Christie J R R 1975 The rise and fall of Scottish science in Crosland $\mathbf{M}$ ed. The emergence of science in western Europe Macmillan, London 111-26; Shapin S 1974 The audience for science in eighteenth century Edinburgh History of Science 12 95-121; Shapin S 1975 Phrenological knowledge and the social structure of nineteenth-century Edinburgh Annals of Science 32 219-43.

6 See, for example, Davie G E 1961 The democratic intellect: Scotland and her universities in the nineteenth century Edinburgh University Press, Edinburgh Chs 5-8; Harwood J 1993 Styles of scientific thought: the German genetics community 1900-1933 University of Chicago Press, Chicago. For earlier systematic attention to national styles of science, see Buckle H T 1903 History of civilization in England 3 vols Grant Richards, London (first published 1857-61) especially Vol. III, Chs 4-5; Merz J T 1965 A history of European thought in the nineteenth century 4 vols Dover, New York (first published 1904-12), especially Vol. I, Chs 1-3.

7 Kuhn T 1962 The structure of scientific revolutions University of Chicago Press, Chicago, is the classic text. For sociological extension and development of Kuhn's work, see, for example, Barnes B 1991 Scientific knowledge and sociological theory Routledge \& Kegan Paul, London; Barnes B 1982 T S Kuhn and social science Macmillan, London; and Bloor 1976 Knowledge and social imagery op. cit. For Kuhn's qualified but definite rejection of this work, see Kuhn T 1992 The trouble with the historical philosophy of science Robert and Maurine Rothschild Distinguished Lecture, 19 November 1991, Department of History of Science, Harvard University, Cambridge, MA.

8 Anglocentric writers sometimes tend to forget that other European languages refer routinely to 'the sciences' (as in the les sciences of the Paris Académie des sciences), while broadly equivalent terms usually include a wide variety of systematically conducted inquiries, so sweeping into words like Wissenschaft,
Wetenschap, Vetenskap and nauki, academic projects customarily regarded in English-speaking cultures as ambiguously scientific or not belonging to science at all. Nevertheless, the Kuhnian point about pluralism stands even when 'science' is taken restrictively as 'natural science'.

9 The interpretative imperative has always been prominent in the ethnographic studies of Harry Collins (see, for example, Collins H 1992 Changing order: replication and induction in scientific practice 2nd edn University of Chicago Press, Chicago (first published 1985); and Collins H 1981 Understanding science Fundamenta Scientiae 2 367-80) while the relationship of other scientific ethnographies to interpretative projects is, at times, unclear: for instance, Latour B and Woolgar S 1986 Laboratory life: the construction of scientific facts 2nd edn Princeton University Press, Princeton (first published 1979).

10 Ophir A and Shapin S eds 1991 The place of knowledge: the spatial setting and its relation to the production of knowledge Special issue of Science in Context 41 , see especially the editors' introduction 'The place of knowledge: a methodological survey' 3-21. The forthcoming work is by Agar J and Smith C eds forthcoming Making space for science: territorial themes in the shaping of knowledge Macmillan, London, and St Martin's Press, New York. Selected studies of the laboratory as a scientific space include: James F A J L ed. 1989 The development of the laboratory: essays on the place of experiment in industrial civilization Macmillan, London; Hannaway $\mathbf{O}$ 1986 Laboratory design and the aim of science: Andreas Libavius versus Tycho Brahe Isis 77 585610; Shapin S 1988 The house of experiment in seventeenth-century England Isis 79 373-404; Owens L 1985 Pure and sound government: laboratories, playing fields, and gymnasia in the nineteenth-century search for order Isis 76 182-94; and Gooding D 1985 'In nature's school': Faraday as an experimentalist in Gooding $\mathbf{D}$ and James F A J L eds Faraday rediscovered: essays on the life and work of Michael Faraday, 1797-1867 Macmillan, London 106-35.

11 For Swedish geographical traditions loosely drawn upon by students of science, see Hägerstrand $\mathbf{T}$ 1967 Innovation diffusion as a spatial process (trans. Pred A) University of Chicago Press, Chicago; and Pred A ed. 1981 Space and time in geography: essays dedicated to Torsten Hägerstrand C W K Gleerup, Lund/Stockholm; for British and French resources well-known to readers of this journal, see, for example, Massey D 1984 Spatial divisions of labour: social structures and the geography of production Macmillan, Basingstoke; Thrift N J 1985 Flies and germs: a geography of knowledge in Gregory D and Urry $\mathbf{J}$ eds Social relations and spatial structures Macmillan, 
Placing the view from nowhere

London 366-403; Bourdieu P 1989 Social space and symbolic power Sociological theory 7 14-25; Lefebvre H 1991 The production of space (trans NicholsonSmith D) Basil Blackwell, Oxford; and Halbwachs M 1980 The collective memory (trans. Ditter F J Jr and Ditter V Y) Harper, New York (first published 1950), especially Ch. 4; for architectural theory, see Hillier B and Hanson J 1984 The social logic of place Cambridge University Press, Cambridge; Hillier B and Penn A 1991 Visible colleges: structure and randomness in the place of discovery Science in Context 4 23-49; for Giddens and geographical sensibilities, see Giddens A 1989 The consequences of modernity Stanford University Press, Stanford, CA.

12 Foucault M 1980 Power/knowledge: selected interviews and other writings 1972-1977 (trans. Gordon C et al.) Harvester, Brighton 69; see also Foucault M 1986 Of other spaces Diacritics 16 22-7; and, for commentary, see Driver F 1992 Geography and power: the work of Michel Foucault in Burke $\mathbf{P}$ ed. Critical essays on Michel Foucault Scolar Press, Aldershot 147-56; Driver F 1994 Bodies in space: Foucault's account of disciplinary power in Jones $\mathbf{C}$ and Porter $\mathbf{R}$ eds Reassessing Foucault: power, medicine and the body Routledge, London 113-31.

13 Livingstone D N 1995 The spaces of knowledge: contributions towards a historical geography of science Environment and Planning D: Society and Space 13 5-34.

14 The following paragraphs draw upon my recent survey: Shapin S 1995 Here and everywhere: sociology of scientific knowledge Annual Review of Sociology 21 289-321, especially 304-9.

15 See, especially, Latour B 1987 Science in action: how to follow scientists and engineers through society Harvard University Press, Cambridge, MA; Latour B 1988 The pasteurization of France (trans. Sheridan $\mathbf{A}$ and Law J) Harvard University Press, Cambridge, MA; Law J 1986 On power and its tactics: a view from the sociology of science Sociological Review 34 1-37; Law J 1987 On the social explanation of technical change: the case of Portuguese maritime expansion Technology and Culture 28 227-52; Law J 1987 Technology and heterogeneous engineering: the case of Portuguese expansion in Bijker W E Hughes T P and Pinch $\mathbf{T} \mathbf{J}$ eds The social construction of technological systems: new directions in the sociology and history of technology MIT Press, Cambridge, MA 111-34.

16 But see forthcoming work by Adrian Johns which powerfully challenges assumptions about the immutability of mechanically produced books: Johns A 1997 The nature of the book: knowledge and print in the making University of Chicago Press, Chicago (based on his 'Wisdom in the concourse: natural philosophy and the history of the book in early modern England', Unpubl. PhD thesis,
Cambridge University, 1992). Roger Lee has interestingly drawn my attention to issues concerned with electronic communication which I am unable to deal with here but see fascinating early engagement with the trustworthiness of such communication in Denning P J 1989 The science of computing: worldnet American Scientist 77 432-4.

17 The following paragraphs sketch some major arguments of mine: Shapin S 1994 A social history of truth: civility and science in seventeenth-century England University of Chicago Press, Chicago. A geographer's guarded assessment of this work is Livingstone D N 1996 High tea at the cyclotron: science as a social practice Books $\mathcal{E}$ Culture January/ February 22-3.

18 For Polanyi, see Polanyi M 1958 Personal knowledge: towards a post-critical philosophy University of Chicago Press, Chicago. For development of Polanyi's sensibilities with respect to tacit knowledge and scientific communication, see Collins 1992 Changing order op. cit.; and, with respect to trust, see Shapin 1994 A social history of truth op. cit.; and Shapin S 1995 Trust, honesty, and the authority of science in Bulger R E Bobby E M and Fineberg H V eds Society's choices: social and ethical decision making in biomedicine National Academy Press, Washington, DC 388-408. See also Hardwig J 1991 The role of trust in knowledge Journal of Philosophy 88 693-708; and Coady C A J 1992 Testimony: $a$ philosophical study Clarendon Press, Oxford.

19 For differing, yet potentially compatible, perspectives on these problems, compare Shapin S 1995 Cordelia's love: credibility and the social studies of science Perspectives on Science 3 255-72; and Porter T 1995 Trust in numbers: the pursuit of objectivity in science and public life Princeton University Press, Princeton.

20 See Jacob J R 1977 Robert Boyle and the English revolution: $a$ study in social and intellectual change Burt Franklin, New York; Jacob J R 1978 Boyle's atomism and the restoration assault on pagan naturalism Social Studies of Science 8 211-33. Much of this moral writing was originally composed earlier, when Boyle was living in Dorset, but Jacob has (rightly, I think) attempted to refer aspects of its meaning to tendencies current when the texts were published later in Boyle's life. Other historians have objected to Jacob's identification of radical sectarian targets, pointing to tendencies in philosophical circles, including Aristotelian and neo-Platonic sensibilities.

21 See Survey of London, general editor Sheppard F H W Vol. XXIX, "The parish of St James Westminster, Part one: south of Piccadilly' Athlone Press, London $365-8,377-8$. Boyle and his sister occupied numbers 83-4 (the house was demolished in 1850). A near neighbour (at numbers 80-2) was the eminent physician Thomas Sydenham, and Nell Gwyn 
(having lived in another Pall Mall house previously occupied by Sydenham) moved into number 79 in 1671. A biographer of Boyle briefly notes these neighbourhood relationships and asks 'What [Boyle] thought of having Nell Gwyn next door to the Countess of Portland, we do not know: he never mentions her' (Maddison R E W 1967 The life of the Honourable Robert Boyle FRS Taylor \& Francis, London 133).

Boyle's laboratory was at the back of his sister's house and may even have had a view of St James's Park and even of the King's private garden. For scenes of licentiousness possibly visible from the laboratory, see de Beer E S ed. 1959 The diary of John Evelyn Oxford University Press, London, 552 (1 March 1671), where Evelyn records that he walked with the King 'thro St James's Parke to the Garden, where I saw and heard a very familiar discourse betweene ... \& Mrs. Nellie as they cal'd an impudent Comedian, she looking out of her Garden on a Terrace at the top of the Wall \& ... standing on the greene Walke under it: I was heartily sorry at this scene: Thence the King walked to the Dutches of Cleavelands, another Lady of Pleasure \& curse of our nation .... That scene over the garden wall was immortalized in a Victorian painting by $\mathrm{C}$ M Ward which now hangs in the Victoria and Albert Museum; see MacGregor-Hastie R 1987 Nell Gwyn Robert Hale, London plate $X$ (facing p. 105).

23 The Royal Society's first President, Sir Robert Moray, had earlier been a friend of Nell and a supplier of her wine and whisky, while Dr Richard Lower, FRS, a scientific associate of Boyle, was one of Nell's physicians at the end of her life. See MacGregor-Hastie 1987 Nell Gwyn op. cit. 43, 99-101, 118-20, 145-6, 165-6, 171, 176, 184, 187; Bevan B 1969 Nell Gwyn Robert Hale, London 88-93. Previous to her residence in Pall Mall, Nell had acted in plays written by Boyle's brother, Lord Orrery, and by another brother's brother-in-law, Thomas Killigrew, so one might also plausibly point to members of his own family as objects of some of Boyle's moral writing. Indeed, the nephew to whom Boyle inscribed some of his early chemical and experimental tracts - Richard Jones, 1st Earl of Ranelagh (Katherine's only son) - grew up to be a dissolute and an embezzler of Crown revenues, and Boyle's niece, Elizabeth Jones (one of Katherine's three daughters), ran off with a footman in 1677.

24 Burke E 1986 Reflections on the revolution in France (O'Brien C C ed.) Penguin, Harmondsworth (first published 1790) 135. 